\title{
Impact of Top Management Support on Accounting Information System: A Case of Enterprise Resource Planning (ERP) System
}

\author{
Collins Otieno Odoyo ${ }^{1, *}$, Patrick B. Ojera ${ }^{2}$ \\ ${ }^{1}$ Department of Information Technology, Masinde Muliro University of Science and Technology, Kenya \\ ${ }^{2}$ School of Business and Economics, Masinde Muliro University of Science and Technology, Kenya
}

Received November 6, 2019; Revised December 19, 2019; Accepted December 25,2019

Copyright $\bigcirc 2020$ by authors, all rights reserved. Authors agree that this article remains permanently open access under the terms of the Creative Commons Attribution License 4.0 International License

\begin{abstract}
Accounting Information System (AIS) is a system that processes financial and nonfinancial transactions that directly affect the organizations operations processing of financial activities such as changes to customers' names and addresses to keep such files current. The purpose of this study was to illustrate the impact of top management support on accounting information systems, a case of Enterprise Resource Planning (ERP) Systems and, further, to analyze the impact of accounting information systems on organizational performance. Online questionnaire was the main tool used for data collection and data was analyzed using descriptive statistics, inferential statistics, as well as while qualitative data was analyzed using thematic analysis. The study established that in the 3 university ERP had already been adopted and was being implemented. Also the Top Management supported the implementation of ERP. The ERP system was not adequately utilized to realize its full potential. It was extensively used on matters related to finance. Especially students finance and managing of the universities payrolls. The systems had not yet been extensively used on managing human resource matters and communication that it had capacity to achieve much. The findings of this study are important as they provide insight that could awaken the institutions that had adopted the ERP systems on how they could optimally benefit from the system. It also highlights the role played by top management on implementation of a new system like ERP. Finally it gives knowledge for fellow scholars interested in the field of Accounting Information Systems generally.
\end{abstract}

Keywords Accounting Information System, AIS, ERP, Enterprise Resource Planning, Organizational Performance

\section{Introduction}

Accounting Information System is a computer based method for tracking accounting activity in through the use of information technology resources [1]. The role of accounting information system is therefore very influential for the organization as it supports the organization's business operations, managerial decision making, and is one of the strategies to achieve the organization's competitive advantage [2]. It is responsible for the collection, storage and processing of financial and accounting data that is used for internal management decision making, including nonfinancial transactions that directly affect the processing of financial transactions.

Accounting Information System is composed of three major subsystems namely: the Transaction Processing System, which supports daily business operations with numerous reports, documents, and messages for users throughout the organization; the general ledger/financial reporting system, which produces the traditional financial statements, such as the income statement, balance sheet, statement of cash flows, tax returns, and other reports required by law; and the management reporting system, which provides internal management with special-purpose financial reports and information needed for decision making such as budgets, variance reports, and responsibility reports [3].

The success of an information system is not only determined by how the system can produce well informed, relevant and reliable information, but is also determined by the external factors to the systems such as compliance with the work environment, support by top management as well as support by the general staff. Technically an information system can be perfect, but it cannot be said to be successful if the users cannot use it [4]. Management support in information systems development and implementation is regarded as an important factor influencing the success or 
failure of the implementation of the system.

\subsection{Accounting information System (AIS) and Enterprise Resource Planning (ERP)}

According to Daoud and Triki [5] ERP system adoption has evolved from use of accounting information systems (AISs). While accounting information systems (AISs) have been limited to preparing financial statements for legal purposes and producing historical accounting and financial information, it is argued that the mission of the AIS has risen from the simple provision of formal and financial information to encompass a broader range of information. The latter propelled by enterprise resource planning (ERP) technology [6]. Daoud and Triki [5] posit that an ERP is a complex set of computer applications designed to integrate the processes and functions within the same entity, presenting a holistic vision of the company's business by sharing a common and integrated database. In consequence, of the era of the ERP system, the AIS has become rich, enabling the use of new management accounting technique, providing both historical and forecasting accounting information that covers financial accounting, management control and financial analysis.

Previous studies have sought to determine the relationship between accounting information systems and business performance [7] [8] [9] [10]. These studies have revealed mixed results. There are, however, few studies which have focused on the role of top management support on Accounting Information Systems.

\subsection{Purpose and Objective of the Study}

In view of the above, the purpose of this study was therefore to illustrate the impact of top management support on accounting information systems, a case of Enterprise Resource Planning (ERP) Systems and, further, to analyze the impact of accounting information systems on organizational performance. This was carried out in Maseno University, Masinde Muliro University of Science and Technology and Jaramogi Oginga Odinga University of Science and Technology.

\section{Literature Review}

\subsection{Enterprise Resource Planning (ERP)}

Enterprise Resource Planning (ERP) has never been easy to explain what it means since every stakeholder has a different perception about what it is as a system [11] [12]. According to Boersma and Kingma [13] (2005) in his article stated that, there would be no universal definition of ERP and that every stakeholder has its own definition depending upon the position in the organization and kind of experience and skills they have.

According to Davenport [14] (1998), ERP is a packaged software product that can be bought off-the-shelf by an organization in order to integrate and share its information and related business processes within and across functional areas, which include but not limited to financial management, human resource management, payroll related issues, procurement and communication among others. As a system, it is a comprehensive, packaged software solutions seeking to integrate the complete range of a business' processes and functions in order to present a holistic view of the business from a single information and Information Technology architecture [12].

\subsubsection{History of ERP}

ERP origin could be traced from Material Requirement Planning (MRP) in 1970s [15]. Such systems were limited to the factory planning and control and were used in converting the systems into small time phrased requirements [16]. Additional elements and attributes had since been added in the MRP and the new modified version was named Manufacturing Resource Planning (MRPII) which had the capacity to integrate the basic functions of production, marketing, sales and finance [17]. In MRPII, units were running on different operating systems which in return made it very difficult to prove itself as a true solution for organization's information systems [18]. Further, there was a problem in protocol incompatibility, interfacing and interoperability as stated by Mohamed and Fadlalla [17]. To overcome the above operational and functionality problem of the MRPII, ERP was introduced as a new package.

\subsubsection{ERP Implementation}

ERP implementation is a challenging task which involve various factors. Such factor when not effectively addressed on put in control, can hurt the implementation strategy and transforms the strategic success into failure [19]. A number of factors have since been found to be the hindrance in the implementation of ERP projects [20].

\subsubsection{Critical Success Factors in ERP Implementation}

ERP implementation is considered to be successful, if it helps the organization in improving financial, technical, economic and strategic position. There are so many critical success factors considered as found out by the various researchers in their studies. These critical factors included but not limited to; top management support, organizational culture, business process reengineering, user training, user involvement, effective communication and, change management among many others.

\subsection{Top Management Support}

Romney and Steinbart [21] states that top management is instrumental in minimizing adverse behavioral reactions, such as resistance to the system being implemented. Their support to any new system being implemented is very key. Thus, top management support is management wishes to provide information and processes required and determine 
the priority of system development. Top management therefore, is not only important for the allocation of the necessary resources, but also give a strong signal to employees that the changes made are essential for the progress of the organization.

According to Bodnar and Hopwood [22], a crucial development of a systems, should ensure that all businesses have got the support of top management. They further stated that careful attention must be given to the development of a system of planning and strategy, which must incorporate the support and approval of top management. Top management support is therefore, an important factor, which determines the effectiveness of the organization's information systems acceptance.

Therefore, top management support is the degree to which senior executives understand the importance of the Information Systems function and are involved in Information Systems activities [23]. Under such circumstances, the executives are interested in the Information Systems function and encourage operating units to collaborate with information systems professionals [24]. Due the position of information systems in any organization that has taken their roles seriously, the executives have considered them as strategic resources and understood the opportunities offered by them [25]. Research has also shown that, the impact of top management support could also be a critical success factor for Information Systems disaster recovery planning [26], and for successful alignment of Information Systems plans with business plans.

Top management support further, leads to the improved quality of shared information in inter-organizational systems usage [27], and to successful software process improvement [28]. Top management support could also influences both perceived ERP system usefulness and usage [29], leads to successful business process management systems implementation [30], and this is a characteristic of successful electronic commerce [31]. On the contrary, lack of top management support leads to failed projects and lost opportunities [32].

\section{Methods and Materials}

This study used a mixed approach of both quantitative and qualitative research approaches. The research design adopted was a case study. The study was conducted in 3 public universities in the Western parts of Kenya namely; Maseno University, Masinde Muliro University of Science and Technology, and Jaramogi Oginga Odinga University of Science and Technology, to establish how top management support, impact on the implementation of ERP. Simple Random Sampling was used to select a total of 30 respondents, 10 from each university, who are working either in finance department and other departments that interacts frequently with ERP. Online questionnaire was the main tool used for data collection, due to its flexibility and convenience for the respondents. Quantitative data was analyzed using descriptive statistics as well as inferential statistics, while qualitative data was analyzed using thematic analysis.

\section{Findings and Discussions}

\subsection{Preliminary Analysis on Study Institutions}

Data for this study was obtained from three (3) public universities in the western part of Kenya. The universities included Maseno University in Kisumu County, Masinde Muliro University of Science and Technology in Kakamega County and finally Jaramogi Oginga Odinga University of Science and Technology in Bondo town, Siaya County. The study was targeting 10 respondents from each of the three public universities selected for this study. Being that the questionnaires used were online tools, it was a little bit challenging to ensure that only 10 respondents from each institution was took part. The response distribution was as follows; 12 respondents from Maseno University, 9 respondents from Jaramogi Oginge Odinga University of Science and Technology, and finally 10 respondents from Masinde Muliro University of Science and Technology, as summarized in fig. 1, below. 


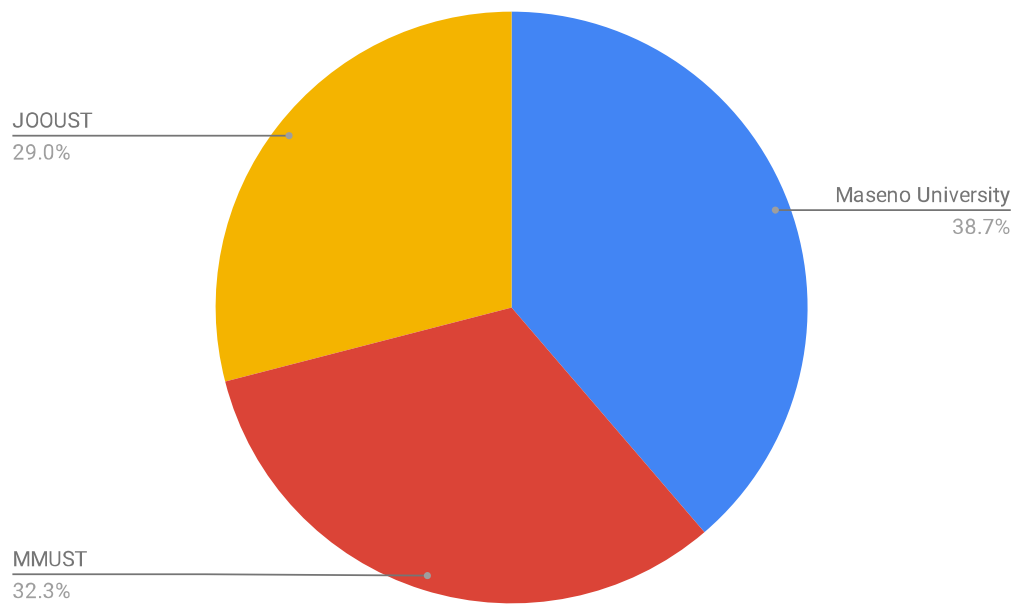

Figure 1. Percentage Respondents Distribution among the 3 Universities

Generally in the 3 university selected for this study, ERP implementation was generally successful at MMUST and JOOUST, while at Maseno University $50 \%$ of the respondents stated it was successful and the other 50\% were of the contrary view. This stated an indifference position in terms of implementation of ERP. On overall these findings indicated that implementation was successful and this is summarized in table 1 below.

Table 1. Was the overall implementation of ERP system successful?

\begin{tabular}{|l|l|l|}
\hline & NO & YES \\
\hline JOOUST & 1 & 8 \\
\hline Maseno University & 6 & 6 \\
\hline MMUST & 3 & 7 \\
\hline Grand Total & $\mathbf{1 0}$ & $\mathbf{2 1}$ \\
\hline
\end{tabular}

Source: Respondents scores 2019

Majority of the respondents were individuals who had worked in the University of Study for relatively longer period of time. This was a strength to this study as it involved those who had better understanding on the way the university they worked for operate and governed. $71 \%$ of the respondent had worked in their work station for more the 3 years. Only $10 \%$ of them had worked for less than 1 year and $19 \%$ had been in their work station for between 1-3 years as illustrated in table 2 .

Table 2. The Duration (in Years) Working the Department

\begin{tabular}{|c|c|c|c|}
\hline & Between 1-3 & Less than 1 & More than 3 \\
\hline JOOUST & 1 & 2 & 6 \\
\hline Maseno University & 1 & 0 & 11 \\
\hline MMUST & 4 & 1 & 5 \\
\hline Grand Total & $\mathbf{6}$ & $\mathbf{3}$ & $\mathbf{2 2}$ \\
\hline
\end{tabular}

Source: Respondents scores 2019

\subsection{Top Management Support on ERP}

The purpose of this study was to illustrate the impact of top management support on accounting information systems, and specifically taking a case of Enterprise Resource Planning (ERP) Systems, that is currently in use in almost all the public universities in Kenya. Further, this study intended to analyze the impact of accounting information systems on organizational performance. Management support can be provided either directly or indirectly. In order to establish management support whether directly or indirectly, the study therefore evaluated; training support, technical support by the Information Technology (IT) staff support, support from service provider, management good will, support from immediate supervisor, and support that employees get from their peers while using or finding challenges with ERP.

\subsubsection{ERP Training Support}

From the study findings, it was established that there was training provided to the staff on the use of ERP to carry out their duties. This was very clear especially for the case of JOOUST and MMUST. The Maseno University case was a bit different, as the respondents' scores revealed that the opportunities offered by management for training on the use of ERP was so limited as illustrated in table 3 below. Training is very instrumental, especially in equipping the staff with all the necessary skills and knowhow that would go a long way in ensuring that they effectively use the system being implemented, to execute their assigned duties.

Table 3. ERP Training as Support from Management

\begin{tabular}{|c|c|c|c|c|}
\hline & $\begin{array}{c}\text { Moderate } \\
\text { Extent }\end{array}$ & $\begin{array}{c}\text { Not } \\
\text { at all }\end{array}$ & $\begin{array}{c}\text { To a great } \\
\text { extent }\end{array}$ & $\begin{array}{c}\text { To a small } \\
\text { extent }\end{array}$ \\
\hline JOOUST & 6 & 0 & 2 & 1 \\
\hline $\begin{array}{c}\text { Maseno } \\
\text { University }\end{array}$ & 1 & 6 & 3 & 2 \\
\hline MMUST & 5 & 1 & 1 & 3 \\
\hline Grand Total & $\mathbf{1 2}$ & $\mathbf{7}$ & $\mathbf{6}$ & $\mathbf{6}$ \\
\hline
\end{tabular}

Source: Respondents scores 2019 
For training to be availed to staff members who need it, the top management must have good will for it. It is at the Top Management level of organization's leadership, where resources for various functions and activities, including staff capacity building are allocated. Frequent staff trainings on ERP use would therefore be attributed to the support directly obtained from the Top Management.

Support by service provider is yet another necessary support that users or implementers of ERP needs. In this case, service providers has been used to refer to the venders of the ERP software packages. Management input is always required in ensuring that service provider offer the necessary support to the ERP users whenever needed. This management support could be delegated of be offered indirectly.

In this particular study, there was generally limited support coming from service provider, except at JOOUST. The limited support coming from service provider is an indication that university do not maintain close contact with the venders as soon as the ERP system is delivered.

\subsubsection{Support by Service Providers}

To benefit from the full range of the products of the ERP system, management should ensure that they maintain close contact with the vender, who would then provide support to systems administrators until such a time when the institution could stand alone in using the services offered by the ERP system. From the finding as illustrated in table 4, management in most of our university were not doing favorably good on this kind of support. It is either that did not see value in such support or that they never set aside financial resources to support follow up help from service providers.

Table 4. Support by Service Provider

\begin{tabular}{|l|c|c|c|c|}
\hline & $\begin{array}{c}\text { Moderate } \\
\text { Extent }\end{array}$ & $\begin{array}{c}\text { Not } \\
\text { at all }\end{array}$ & $\begin{array}{c}\text { To a great } \\
\text { extent }\end{array}$ & $\begin{array}{c}\text { To a small } \\
\text { extent }\end{array}$ \\
\hline JOOUST & 2 & 0 & 3 & 4 \\
\hline $\begin{array}{l}\text { Maseno } \\
\text { University }\end{array}$ & 4 & 0 & 0 & 8 \\
\hline MMUST & 3 & 3 & 0 & 4 \\
\hline Grand Total & $\mathbf{9}$ & $\mathbf{3}$ & $\mathbf{3}$ & $\mathbf{1 6}$ \\
\hline
\end{tabular}

Source: Respondents scores 2019

\subsubsection{Support from the IT Technical Staff}

For the successful implementation of ERP, there is need for skilled Technical staff. This is a team led by the system administrator. Members of this team need to be deployed to departmental levels where ERP are extensively being utilized. It is this team that needed to be skilled through training in order for them to give support to the rest of the staff. It is also this team that need from time to time to be in close contact with the service provider, and facilitated by the management. To this extent they would be performing a delegated role to keep in touch with the vendor on behalf of the leadership of the university. From this study, in the selected universities, support from the technical staff to other staff using ERP, whether in human resource department or fiancé department was very low, especially the case in Maseno University and MMUST. JOOUST on the other had had an indifferent finding with respect to technical support. This information is illustrated in table 5.

Table 5. Technical Support by IT people

\begin{tabular}{|l|c|c|c|}
\hline & $\begin{array}{c}\text { Moderate } \\
\text { Extent }\end{array}$ & $\begin{array}{c}\text { To a great } \\
\text { extent }\end{array}$ & $\begin{array}{c}\text { To a small } \\
\text { extent }\end{array}$ \\
\hline JOOUST & 0 & 5 & 4 \\
\hline $\begin{array}{l}\text { Maseno } \\
\text { University }\end{array}$ & 1 & 3 & 8 \\
\hline MMUST & 2 & 1 & 7 \\
\hline Grand Total & $\mathbf{3}$ & $\mathbf{9}$ & $\mathbf{1 9}$ \\
\hline
\end{tabular}

Source: Respondents scores 2019

\subsubsection{Direct Management Support and Goodwill}

The study also looked at the goodwill from management towards implementation of the ERP systems. The good will towards using the ERP system in human resource related matters, communication, handling students' records which include students finance, university financial transactions among many others. Table 6 illustrate that, there was at least some form of goodwill by management in all the 3 universities that were selected for this study.

Table 6. Management Support and Goodwill

\begin{tabular}{|l|c|c|c|}
\hline & $\begin{array}{c}\text { Moderate } \\
\text { Extent }\end{array}$ & $\begin{array}{c}\text { To a great } \\
\text { extent }\end{array}$ & $\begin{array}{c}\text { To a small } \\
\text { extent }\end{array}$ \\
\hline JOOUST & 5 & 2 & 2 \\
\hline $\begin{array}{l}\text { Maseno } \\
\text { University }\end{array}$ & 9 & 3 & 0 \\
\hline MMUST & 5 & 1 & 4 \\
\hline Grand Total & $\mathbf{1 9}$ & $\mathbf{6}$ & $\mathbf{6}$ \\
\hline
\end{tabular}

Source: Respondents scores 2019

\subsubsection{Support from Immediate Supervisors}

From the respondents scores illustrated in table 7 below, there was adequate support from the immediate supervisors, at least in all the 3 universities where this study was conducted. These immediate supervisors to systems users are the departmental heads. This indicated that other than the support from the top management, there was also support from the heads of departments and section in the implementation of ERP system.

Table 7. Support from Immediate supervisor

\begin{tabular}{|l|c|c|c|c|}
\hline & $\begin{array}{c}\text { Moderate } \\
\text { Extent }\end{array}$ & $\begin{array}{c}\text { Not } \\
\text { at all }\end{array}$ & $\begin{array}{c}\text { To a great } \\
\text { extent }\end{array}$ & $\begin{array}{c}\text { To a small } \\
\text { extent }\end{array}$ \\
\hline JOOUST & 4 & 0 & 3 & 2 \\
\hline $\begin{array}{l}\text { Maseno } \\
\text { University }\end{array}$ & 6 & 1 & 5 & 0 \\
\hline MMUST & 3 & 2 & 1 & 4 \\
\hline Grand Total & $\mathbf{1 3}$ & $\mathbf{3}$ & $\mathbf{9}$ & $\mathbf{6}$ \\
\hline
\end{tabular}

Source: Respondents scores 2019 


\subsubsection{Support from Peers and Colleagues}

Also worth noting is the support that was coming from peers. Such support was instrumental as it enhanced synergy among members of staff, making them support each other on their individual duties. Peer support also has a potential of building confidence among the staff members, in addition to promoting inclusivity of all staff. In the 3 study universities, this kind of support was present and the scores are illustrated in table 8 below.

Table 8. Support from peers

\begin{tabular}{|l|c|c|c|}
\hline & $\begin{array}{c}\text { Moderate } \\
\text { Extent }\end{array}$ & $\begin{array}{c}\text { To a great } \\
\text { extent }\end{array}$ & $\begin{array}{c}\text { To a small } \\
\text { extent }\end{array}$ \\
\hline JOOUST & 5 & 2 & 2 \\
\hline $\begin{array}{l}\text { Maseno } \\
\text { University }\end{array}$ & 8 & 4 & 0 \\
\hline MMUST & 3 & 3 & 4 \\
\hline Grand Total & $\mathbf{1 6}$ & $\mathbf{9}$ & $\mathbf{6}$ \\
\hline
\end{tabular}

Source: Respondents scores 2019

From this study it was eminent that generally there was support from the top management towards the implementation of the ERP system. However in a few instances there was limited support in specific universities as had already been discussed in the section above and illustrated in the tables above. This kind of support further had a far reaching effects on the performance of the organization.

\subsection{Impacts from Various Supports}

\subsubsection{Improved Communication in the Universities}

The study established that ERP is improving performance in a number of sectors within the organization where implementation already was taking place. To begin with, the system was not fully implemented to enhance communication within the university. The findings stated that ERP on matters of communication was utilized to either small extent or just a moderate extent as indicated in table 9 below. This finding illustrate that there was still room for the universities exploit in terms of effective communications at various levels of the university.

Table 9. ERP has improved communication in the university

\begin{tabular}{|l|c|c|c|}
\hline & $\begin{array}{c}\text { Moderate } \\
\text { extent }\end{array}$ & $\begin{array}{c}\text { To a great } \\
\text { extent }\end{array}$ & $\begin{array}{c}\text { To a small } \\
\text { extent }\end{array}$ \\
\hline JOOUST & 2 & 3 & 4 \\
\hline $\begin{array}{l}\text { Maseno } \\
\text { University }\end{array}$ & 9 & 0 & 3 \\
\hline MMUST & 2 & 0 & 8 \\
\hline Grand Total & $\mathbf{1 3}$ & $\mathbf{3}$ & $\mathbf{1 5}$ \\
\hline
\end{tabular}

Source: Respondents scores 2019

\subsubsection{Improved Management of Students Financial Records and Payroll Services}

The impact of ERP implementation was eminent on financial management. The findings illustrated and are summarized in table 10, that were implementing ERP in their financial records management. This could mean that there were benefits experienced in using the system in such a sensitive sector of an institution. No organization can trust faulty or system with low or no return in their financial sector. This was a clear indication that the benefits that ERP granted to the universities were great. Close to this point is management of the payroll. The 3 universities where this study was conducted were all using this system to manage their payroll. Table 11 clearly illustrates the confidence the institutions had on ERP to manage their payroll system.

Table 10. ERP has improved management of students financial records

\begin{tabular}{|l|c|c|c|}
\hline & $\begin{array}{c}\text { Moderate } \\
\text { extent }\end{array}$ & $\begin{array}{c}\text { To a great } \\
\text { extent }\end{array}$ & $\begin{array}{c}\text { To a small } \\
\text { extent }\end{array}$ \\
\hline JOOUST & 6 & 3 & 0 \\
\hline $\begin{array}{l}\text { Maseno } \\
\text { University }\end{array}$ & 7 & 5 & 0 \\
\hline MMUST & 6 & 1 & 3 \\
\hline Grand Total & $\mathbf{1 9}$ & $\mathbf{9}$ & $\mathbf{3}$ \\
\hline
\end{tabular}

Source: Respondents scores 2019

Table 11. ERP has made payroll services efficient

\begin{tabular}{|l|c|c|c|}
\hline & $\begin{array}{c}\text { Moderate } \\
\text { extent }\end{array}$ & $\begin{array}{c}\text { To a great } \\
\text { extent }\end{array}$ & $\begin{array}{c}\text { To a small } \\
\text { extent }\end{array}$ \\
\hline JOOUST & 4 & 5 & 0 \\
\hline $\begin{array}{l}\text { Maseno } \\
\text { University }\end{array}$ & 6 & 6 & 0 \\
\hline MMUST & 3 & 4 & 3 \\
\hline Grand Total & $\mathbf{1 3}$ & $\mathbf{1 5}$ & $\mathbf{3}$ \\
\hline
\end{tabular}

Source: Respondents scores 2019

\subsubsection{Improved Human Resource Management in the Universities}

The ERP system has potential to improve how matters related to human resources are managed, however from the study and as illustrated in table 12, most universities had fully adopted ERP for their human resource management and related matters. The adoption that was at the human resource level was just to a small extent.

Table 12. Human Resource matters are managed through ERP

\begin{tabular}{|l|c|c|c|}
\hline & $\begin{array}{c}\text { Moderate } \\
\text { extent }\end{array}$ & $\begin{array}{c}\text { Not at } \\
\text { all }\end{array}$ & $\begin{array}{c}\text { To a small } \\
\text { extent }\end{array}$ \\
\hline JOOUST & 5 & 0 & 4 \\
\hline $\begin{array}{l}\text { Maseno } \\
\text { University }\end{array}$ & 0 & 6 & 6 \\
\hline MMUST & 1 & 1 & 8 \\
\hline Grand Total & $\mathbf{6}$ & $\mathbf{7}$ & $\mathbf{1 8}$ \\
\hline
\end{tabular}

Source: Respondents scores 2019

\section{Conclusions}

As shown in this paper this work identifies many of the aspects of top management support to Accounting 
Information Systems (AIS) a case of ERP systems used in most the Kenyan universities currently. ERP systems as could be seen in the work of this study, had been adopted in the universities to run most of the activities in the universities. What was different was the level of adoption or just the level of implementation. The various universities are at different levels of implementing ERP systems, and also their preference on which aspect to use the ERP differed.

The system seems to have been fully embraced on managing financial matters ranging from students finance records to payroll system as well as payment to suppliers. The findings indicated the great confidence that the institutions have in using systems to manage their financial records. This could be said had blessing of the management who are the strategic decision makers.

However, management needs to encourage the use of ERP in handling human resources related matters. Matters like employee leave request and approvals, despite the fact that could be done through the systems, were still handled manually. Also there was limited use of ERP in enhancing communication compared to its full potential.

\section{REFERENCE}

[1] Fontinelle. A., (2013). Introduction to Accounting Information Systems. Available: http://www.investopedia. com/articles/professionaleducation/11/accounting-informat ion-systems.asp Retrieved on 31st May, 2019

[2] O'Brien, J. A., \& Marakas, G. M., (2008) Introduction to Information Systems, Fourteenth Edition, McGraw - Hill Irwin, New York

[3] Hall, J. A., (2010) Accounting Information Systems: South Western Educational Publishing.

[4] Choe, J., (1996) The Relationships among Performance of Accounting Information Systems, Influence Factors, and Evolution level of Information Systems. Journal of Management Information Systems.

[5] Daoud, H and Triki, M (2013). Accounting Information Systems in an ERP Environment and Tunisian Firm Performance The International Journal of Digital Accounting Research Vol. 13, 2013, pp. 1 - 35 ISSN: $1577-8517$

[6] Chenhall, R.H. (2003): "Management control systems design within organisational context: findings from contingency-based research and directions for the future", Accounting, Organisation and Society, vol. 28: 127-168. http://dx.doi.org/10.1108/18347641011023270

[7] Affes, H.; Chabchoub, A. (2007): "Le système d'information comptable: les déterminants de ses caractéristiques et son impact sur la performance financière des PME en Tunisie", La Revue des Sciences de Gestion: Direction et Gestion, vol. 42, n. 224/225: 59-70. http://dx.doi.org/10.1051/larsg:2007018
[8] Boulianne, E. (2007): "Revisiting fit between AIS design and performance with the analyzer strategic-type", International Journal of Accounting Information Systems, vol. 8: 1-16. http://dx.doi.org/10.1016/j.accinf.2006.12.001

[9] Karruddin, S.; Ashhari, Z.M.; Nassir, A.M. (2010): "Information system and firms' performance: the case of Malaysian small medium enterprises", International Business Research, vol. 3, n. 4: 28-35.

[10] Grande, E.U.; Estebanez, R.P.; Colomina, C.M. (2011): "The impact of Accounting Information Systems (AIS) on performance measures: empirical evidence in Spanish SME", International Journal of Digital Accounting Research, vol. 11: 25-43. http://dx.doi.org/10.4192/1577-8 517-v11 2

[11] Al-Mashari, M., \& Al-Mudimigh, A., (2003) ERP implementation: lessons from a case study. Information Technology \& People, 16(1): p. 21-33.

[12] Klaus, H., M. Rosemann, and G.G. Gable, (2000). What is ERP? Information systems frontiers, 2(2): p. 141162.

[13] Boersma, K. and S. Kingma, (2005). Developing a cultural perspective on ERP. Business Process Management Journal, 11(2): p. 123-136.

[14] Davenport, T.H., (1998) Putting the enterprise into the enterprise system. Harvard business review, 76(4).

[15] Wortmann, J., H. Hegge, and S. Rolefes, (2000) Embedding enterprise software in extended enterprise models. Computers in Industry, 42(2): p. 231-243.

[16] Orlicky, J.A., (1974). Material requirements planning: the new way of life in production and inventory management. McGraw-Hill, Inc.

[17] Mohamed, M. and A. Fadlalla, (2005). ERP II: harnessing ERP systems with knowledge management capabilities. Journal of Knowledge Management Practice, 1(2): p. 1.

[18] Chung, S.H. and C.A. Snyder, (2000). ERP adoption: a technological evolution approach. International Journal of Agile Management Systems 2(1): p. 2432.

[19] Shah, S.I.H., (2011). Socio-technical factors affecting ERP implementation success in Pakistan: an empirical study. Australian Journal of Basic and Applied Sciences, 5(3): p. 742-749.

[20] Moohebat, M.R., A. Asemi, and M.D. Jazi, (2010). A comparative study of critical success factors (CSFs) in implementation of ERP in developed and developing countries. International Journal, 2(5): p. 99-110.

[21] Romney, M. B., \& Steinbarts, P. J., (2004). Accounting Information Systems. Translators by Fitria Sari Dewi, Jakarta: Four Salemba.

[22] Bodnar, G. H., \& Hopwood, W. S., (2004). Accounting Information Systems. Ninth Edition. Upper Saddle River, New Jersey: Pearson Education Inc.

[23] Ragu-Nathan, B.S., Apigian, C.H., Ragu-Nathan, T.S., \&Tu, Q. (2004).A path analytic study of the effect of top management support for information systems performance. Omega, 32 (6), 459-471.

[24] Boynton, A.C., Jacobs, G.C., \& Zmud, R. W. (1992).Whose 
responsibility is IT management? Sloan Management Review, 33 (4), 32-38.

[25] Clemons, E., Kauffman, R., \&Weber, T. (2009).Special section: competitive strategy, economics, and information systems. Journal of MIS, 26 (2), 7-13.

[26] Chow W.S. and Ha, W.O. (2009).Determinants of the critical success factor of disaster recovery planning for information systems. Information Management \& Computer Security, Bradford 17 (3), 248.

[27] Hartono, E., Li, X., Na, K-S., \&Simpson, J.T. (2010).The role of the quality of shared information in inter-organizational systems use, International Journal of Information Management,30(5),399-407.

[28] Ngwenyama, O., \& Nørbjerg, J. (2010).Software process improvement with weak management support: an analysis of the dynamics of intra-organizational alliances in IS change initiatives. European Journal of Information Systems, 19 (3), 303-319.

[29] Lin, H-F. (2010).An investigation into the effects of IS quality and top management support on ERP system usage. Total Quality Management \& Business Excellence, 21 (3), 335-349.

[30] Ravesteyn, P., and Batenburg, R. (2010).Surveying the critical success factors of BPM-systems implementation, Business Process Management Journal, 16 (3), 492-507.

[31] Epstein. M.J. (2005).Implementing successful e-commerce initiatives. Strategic Finance 86 (9), 22-29.

[32] Andriole S. J. (2009). Boards of directors and technology governance: the surprising state of the practice. Communications of the Association for Information Systems, 24 (1), 58. 